\title{
General Management of the Patient: Specific Aspects of Children
}

\author{
Francesca Riccardi and Elio Castagnola
}

\subsection{Introduction}

Many of the conditions requiring allo-HSCT and related complications are similar in adults and children and are covered in other chapters of this handbook.

However, since pediatric age is a continuum between newborns and adults, there are at least two aspects, psychological and infectious disease issues, that may require a dedicated approach for the following reason:

1. Psychological aspects. Childhood encompasses different ages and consequently different cognitive, decisional, and emotional capacities that make psychological intervention far more faceted than in adults. In addition, psychological intervention should also take in charge at higher extent the needs and the expectations of the patient's family.

2. Infectious diseases. Data on epidemiology and management of infections in children are far less numerous and consistent than in adults. In addition most of the available data are derived from studies in adults, and they

F. Riccardi

Consultant Hematology Unit, Hemato-Oncology and SCT Pole, Istituto Giannina Gaslini, Genoa, Italy

E. Castagnola $(\bowtie)$

Infectious Diseases Unit, Department of Pediatrics, Istituto Giannina Gaslini, Genoa, Italy

e-mail: eliocastagnola@gaslini.org cannot always simply be transposed to children for an effective application.

In the following paragraphs, we will analyze the specific approaches related to these aspects in children undergoing HSCT.

\subsection{Psychological Aspects (Table 28.1)}

Children who undergo HSCT experience several numerous psychological reactions: anxiety, depression, behavioral and social problems, and post-traumatic stress symptoms. In the stages before HSCT, anxiety increases, and the emotional distress continues to rise until 1 week after transplant, whereas depression is heightened by hospitalization and physical isolation. Age ( $<7$ years) and severity of the illness influence the level of emotional reactions. Especially, children $<5$ years are more likely to withdraw and to be deprived of their self-help skills and even of their mobility and speech skills. The level of pre-HSCT emotional disturbance is strongly predictive of post-HSCT emotional functioning; therefore early intervention appears of critical importance (Packman et al. 2010).

The most studied psychological treatments for children with cancer are cognitive behavioral therapies (CBT) that are considered to improve emotional adjustment, compliance with medical 
Table 28.1 Main psychological problems in HSCT in pediatric age

\begin{tabular}{|c|c|c|}
\hline & Problems & Suggested intervention \\
\hline Patients & $\begin{array}{l}\text { Emotional disturbance: anxiety, depression, } \\
\text { behavioral and social problems, post traumatic } \\
\text { stess symptoms } \\
\text { HRQOL: compromission is evident before and } \\
\text { soon after HSCT. Start to improve between } 4 \\
\text { and } 6 \text { months after HSCT } \\
\text { Neurocognitive area: impairment is associated } \\
\text { with younger age at diagnosis and treatment. } \\
\text { Adaptive skills and social competence are } \\
\text { affected in the first year after HSCT }\end{array}$ & $\begin{array}{l}\text { - Individual therapies to improve emotional } \\
\text { adjustment, compliance with medical } \\
\text { treatment and behavioral problems } \\
\text { associated with HSCT } \\
\text { - Guided imagery, distraction, rhythmic } \\
\text { breathing, relaxation to decrease the } \\
\text { distress due to medical procedures } \\
\text { - Clinical assessment is recommended: } \\
\text { before the recovery period } 1 \text { year after HSCT } \\
\text { annually thereafter }\end{array}$ \\
\hline Siblings & $\begin{array}{l}\text { Post-traumatic stress reactions, anxiety, low } \\
\text { self-esteem, feelings of guilt and school } \\
\text { problems }\end{array}$ & $\begin{array}{l}\text { Open communication } \\
\text { Facilitate the access of sibling to the hospital }\end{array}$ \\
\hline Parents & $\begin{array}{l}\text { Parental distress, anxiety, depression, post } \\
\text { traumatic stress symptoms. Take care of } \\
\text { additional burden due to medical complications }\end{array}$ & $\begin{array}{l}\text { Familial intervention } \\
\text { Crisis intervention approach } \\
\text { Stress and coping models }\end{array}$ \\
\hline
\end{tabular}

treatment, and behavioral problems associated with HSCT. Effective interventions are clearly largely dependent on social skills and emotional well-being. Techniques such as guided imagery, distraction, rhythmic breathing, and relaxation are commonly used to decrease the acute psychological distress due to medical procedures including HSCT (Packman et al. 2010). Psychiatric assessment and pharmacological approach should be advisable when other approaches are not sufficient for children with preexisting psychiatric diagnoses who are vulnerable to worsening of the psychiatric disorders (Steele et al. 2015).

Health-related quality of life (HRQOL) compromission is usually evident prior to and soon after transplant and starts to improve between 4 and 6 months after HSCT. Child psychosocial problems, caregiver stress, and social support emerged as significant predictors of physical and emotional outcome after discharging. Indeed, high level of stress of caregivers and/or low perceived social support was associated with higher risk of psychologically complicated outcome. On the contrary emotional and behavioral problems of the child at discharge were not associated to substantially slower improvements in overall HRQOL that usually occurred between 3 and 9 months after discharge. This is because reestablishment of usual activities that were precluded during HSCT outbalances emotional problems due to the return to "normal" life (Loiselle et al. 2016).

As for neurocognitive functions, long-term studies are not fully concordant, but some findings (Kelly et al. 2018) seem to suggest that children's intelligence quotient (IQ) scores post HSCT are inferior to those before HSCT. In particular adaptive skills and social competence domains are affected in the first year after HSCT and so do self-esteem and emotional well-being. Impairment in neurocognitive area is associated with younger age at diagnosis and treatment and may occur even if school performance remains in normal ranges. Children may also experience decrements in executive functioning skills, like deficits in fine motor abilities usually seen in patients who received cranial irradiation at younger age. Clinical assessment is recommended before the recovery period, at 1 year after HSCT and annually thereafter, or, at least, at the beginning of each stage of education. In the post-HSCT assessment, clinicians should also consider the impact of factors such as isolation, missed schooling, and impaired socialization with peers. Encouraging results in cognitive rehabilitation come from intensive therapist-delivered training since the systematic use of computer-based training appeared to improve working memory and processing speed (Kelly et al. 2018). 
Siblings, either donors or non-donors, are at risk of developing emotional disturbances such as post-traumatic stress reactions, anxiety, low self-esteem, feelings of guilt, and school problems. Indeed, researches are needed to identify the most useful intervention to cope with negative effects of HSCT on siblings (Packman et al. 2010; Gerhardt et al. 2015). Currently adopted strategies include open communication about the patient's medical situation and transplant process, favoring the idea of accepting help from friends and family members, and facilitating the access of sibling to the hospital arranging visits in a way that they look like a special event or assigning a sibling a special role (Gerhardt et al. 2015; White et al. 2017).

Parental distress, anxiety, and depression levels are often increased as a result of their child undergoing HSCT. The distress and anxiety may be even greater for parents whose healthy child also becomes part of the HSCT process through donating his/her marrow (Packman et al. 2010). Significant determinants of parental distress include prior parent and patient experience of distress associated with the child's illness, the child's tendency of internalizing or externalizing behavior problems, the family's attitude to provide support, and a parental proneness toward avoidant coping behaviors (Phipps et al. 2005). Parents mostly experience post-traumatic stress symptoms that manifest in cognitive and behavioral efforts to avoid reminders of the HSCT and intrusive thoughts about it (Virtue et al. 2014).

Early and late HSCT medical complications significantly increase the psychological involvement of the caregiver. HSCT healthcare professionals should also take care of the additional burden that complications generate on the parents and should proactively link parents to resources aimed to help them coping with this extra load (Heinze et al. 2015). Despite the recognized needs, very few caregivers seek out psychological service. The most frequent barriers are that clinicians prioritize medical patient's needs and cover tasks usually deemed to social support, lack of adequate locations, and embarrassment about seeking psychological counseling (Devine et al. 2016).

Familial interventions aimed to enhance protective factors, improve communication, and decrease parental anxiety and depression are crucial. In this respect, cancer-specific psychological interventions may serve as a template to delivering HSCT-tailored interventions (Packman et al. 2010). Traditional individual therapy is very useful even if in adapted forms. Usually it includes crisis intervention approach and stress and coping models to reduce HSCT-related stress. CBT can encompass different strategies such as the expression of emotional feelings, identification of distorted automatic thoughts, the use of problem-focused coping skills, discussion of psychosocial impact on the family, and training in assertiveness and communication skills (Steele et al. 2015).

\subsection{Infectious Diseases}

Infections represent one of the most frequently occurring and feared complications of HSCT.

Antibacterial prophylaxis for febrile neutropenia is frequently administered in pediatric HSCT but never specifically analyzed in a randomized clinical trial. Its use can be associated with selection of resistant strains.

In the pre-engraftment phases, empirical antibiotic therapy for febrile neutropenia could be represented by monotherapy with an antiPseudomonas beta-lactam, but it is mandatory its adaptation to local epidemiological data (Lehrnbecher et al. 2017). Moreover, empirical antibiotic therapy should be considered also after engraftment because of the important risk of morbidity and mortality. Antibiotic-resistant pathogens represent a new challenge because of the high mortality rates $(>50 \%)$ observed in pediatric HSCT (Girmenia et al. 2015; Caselli et al. 2016).

Clostridium difficile may represent a cause of severe, and sometimes recurrent, disease, but it must be kept in mind that children aged below 2 years may harbor this pathogen in their intestinal tract (Lees et al. 2016; 
Enoch et al. 2011) and that other pathogens (e.g., viruses or Cryptosporidium) could be the cause of gastroenteritis (Castagnola et al. 2016). Table 28.2 summarizes antibacterial drugs for prophylaxis and treatment of invasive diseases.

Invasive fungal disease (IFD) is associated with high mortality in pediatric HSCT (Cesaro et al. 2017; Castagnola et al. 2018b). Increasing age has been identified as a risk factor for the development of IFD (Fisher et al. 2017), but recent multivariable analyses showed that age is no longer significant in the presence of severe acute or chronic extensive GvHD or in cases of primary graft failure or rejection (Castagnola et al. 2014, 2018a).

Primary prophylaxis should be implemented in the highest-risk groups like patients with primary graft failure or rejection, or with severe acute or chronic extensive GvHD, or in centers with high incidence of IFD (Groll et al. 2014).

Table 28.2 Prophylaxis and therapy of invasive bacterial infections in children undergoing allogeneic HSCT

\begin{tabular}{|c|c|}
\hline \multicolumn{2}{|r|}{ Prophylaxis for febrile neutropenia } \\
\hline Ciprofloxacin & $\begin{array}{l}\text { Oral or IV until neutrophil recovery or start of empirical therapy for febrile neutropenia } \\
\text { Notes: Never analyzed in a randomized clinical trial in HSCT. Risk of selection of resistant } \\
\text { strains }\end{array}$ \\
\hline $\begin{array}{l}\text { Amoxicillin- } \\
\text { clavulanate }\end{array}$ & $\begin{array}{l}\text { Oral or IV until neutrophil recovery or start of empirical therapy for febrile neutropenia } \\
\text { Notes: Never analyzed in a randomized clinical trial in HSCT. Risk of selection of resistant } \\
\text { strains }\end{array}$ \\
\hline \multicolumn{2}{|r|}{ Empirical therapy for febrile neutropenia, or fever after engraftment, especially in presence of GvHD } \\
\hline Pipera-tazo & $100 \mathrm{mg} / \mathrm{kg}(\mathrm{max} 4000 \mathrm{mg}$ ) of piperacillin $\mathrm{q} 6 \mathrm{~h}$ \\
\hline Cefepime & $33 \mathrm{mg} / \mathrm{kg}(\max 2000 \mathrm{mg}) \mathrm{q} 8 \mathrm{~h}$ \\
\hline Ceftazidime & $33 \mathrm{mg} / \mathrm{kg}(\max 2000 \mathrm{mg})$ \\
\hline Meropenem & $\begin{array}{l}20 \mathrm{mg} / \mathrm{kg} \text { ( } \max 1000 \mathrm{mg}) \mathrm{q} 8 \mathrm{~h} \\
\text { Notes: Risk of selection of resistant Gram-negatives or } C \text {. difficile associated disease. Higher } \\
\text { doses could be necessary for treatment of carbapenem resistant pathogen when MIC is } \\
\leq 16 \mathrm{mg} / \mathrm{L} \text {. For higher MIC values carbapenems are not indicated }\end{array}$ \\
\hline $\begin{array}{l}\text { Combination } \\
\text { therapy }\end{array}$ & $\begin{array}{l}\text { Aminoglycoside [e.g. amikacin } 20 \mathrm{mg} / \mathrm{kg}(\mathrm{max} 1500 \mathrm{mg}) \mathrm{q} 24 \mathrm{~h}]+ \text { beta-lactam } \\
\text { Notes: According to local susceptibility, and proportions of resistance to beta-lactams indicated } \\
\text { for monotherapy }\end{array}$ \\
\hline \multicolumn{2}{|r|}{ Documented infections: according with localizations and antibiotic susceptibility tests } \\
\hline $\begin{array}{l}\text { Antibiotics for } \\
\text { resistant } \\
\text { pathogens, } \\
\text { combinations } \\
\text { could be needed }\end{array}$ & $\begin{array}{l}\text { Gram-positives: vancomycin, teicoplanin daptomycin, linezolid, tigecycline, fosfomycin } \\
\text { Gram-negatives: ciprofloxacin, colistin, tigecycline (not active against P. aeruginosas), } \\
\text { fosfomycin, ceftazidime-avibactam (not active against metallo beta-lactamases), ceftolozane- } \\
\text { tazobactam (not active against carbapenemases) } \\
\text { Notes: } \\
\text { - According to ATB susceptibility tests in documented infections } \\
\text { - Beta-lactams should be preferred to glycopeptides in case of infections due to oxacillin- } \\
\text { susceptible staphylococci } \\
\text { - Do not use empirical glycopeptides for persistent fever without signs of localizations } \\
\text { attributable to Gram-positives or high suspicion or risk by patient's history or local } \\
\text { epidemiology of oxacillin-resistant staphylococci or ampicillin-resistant enterococci } \\
\text { - For vancomycin resistant staphylococci or enterococci daptomycin, linezolid or tigecycline } \\
\text { could represent therapeutic options } \\
\text { - No PK data for ceftazidime-avibactam or ceftolozane-tazobactam available in children }\end{array}$ \\
\hline \multicolumn{2}{|r|}{ Clostridium difficile associated disease } \\
\hline $\begin{array}{l}\text { Vancomycin, } \\
\text { metronidazole, } \\
\text { fidaxomicin }\end{array}$ & $\begin{array}{l}\text { Oral therapy, vancomycin } 10 \mathrm{mg} / \mathrm{kg}(\max 125 \mathrm{mg}) \mathrm{q} 6 \mathrm{~h} \text { as } 1 \mathrm{st} \text { choice } \\
\text { Fidaxomicin is not registered for }<18 \text { years } \\
\text { Notes: No data are available for fecal transplantation in immunocompromised children. Different } \\
\text { dosages proposed for recurrent disease }\end{array}$ \\
\hline
\end{tabular}

MIC minimally inhibitory concentration, GvHD graft vs. host disease, Pipera-tazo Piperacillin-Tazobactam 
Diagnosis of IFD is based on isolation of fungal pathogens from cultures of sterile sites or tissue invasion demonstrated by histology or by the presence of fungal antigens in blood or cerebrospinal fluid or bronchoalveolar lavage, associated with suggestive imaging (Castagnola et al. 2016; Tomà et al. 2016) in children with a compatible clinical picture. Detection of galactomannan and 1-3-beta-Dglucan is widely used for the diagnosis of (probable) IFD also in children. However, a recent meta-analysis (Lehrnbecher et al. 2016) and new clinical data (Calitri et al. 2017) showed highly variable and generally poor sensitivity, specificity, and predictive values of these tests, especially when used for screening. PCR should still be considered as an investigative test (Lehrnbecher et al. 2016). Also, for the use of antifungal drugs, there are caveats.

Treatment: Voriconazole frequently needs to be administered at higher dosages in the youngest patients ( $<5$ years) to achieve and maintain effective plasma concentrations $(\mathrm{Xu}$ et al. 2016; Soler-Palacin et al. 2012; Neely et al. 2015; Castagnola and Mesini 2018). Inflammation, steroid administration, or obesity can further modify its concentrations (Castagnola and Mesini 2018; Natale et al. 2017) and so do genetic factors (Teusink et al. 2016). Finally, severe cutaneous adverse events can be observed also in children when voriconazole is administered for prolonged periods, especially in concomitance with sun exposure (Goyal et al. 2014; Bernhard et al. 2012). Posaconazole oral suspension has variable absorption implying the risk of sub-therapeutic concentrations (Jancel et al. 2017), especially in the presence of intestinal acute GvHD (Heinz et al. 2016). This can be at least partially avoided by fatty meal and/or other "bundle" measures or using doses based on body surface area (Castagnola and Mesini 2018). Posaconazole tablets have no absorption problems, and pediatric pharmacological data show that their use determines effective concentrations also in children (Castagnola and Mesini 2018). However, tablets are slightly less than $2 \mathrm{~cm}$ long and should be swallowed whole with water and should not be crushed, chewed, or broken (EMA 2018) thus limiting their use in youngest patients, but alternate day administration could represent an effective strategy (Mesini et al. 2018). Triazoles have also many drug interactions that must be kept in mind during their use. For all these reasons, therapeutic drug monitoring is mandatory both for prophylactic and therapeutic uses (Groll et al. 2014).

Pneumocystis jirovecii pneumonia is a severe, life-threatening fungal infection in alloHSCT recipients. Primary prophylaxis is highly recommended in children undergoing alloHSCT at least in the post-engraftment. Prophylaxis is highly effective, and in case of documented failure, especially in adolescents, compliance must be checked (Castagnola and Mesini 2018). Table 28.3 summarizes dosages of drugs for prevention or treatment of IFD in children.

Viral Infections No major differences between children and adults are expected. However, primary viral infections are more frequent in pediatrics, and in this setting, it must be stressed that healthy household contacts and healthcare workers may represent important sources, with possible hospital spreading.

Screening and Isolation Application of bundle procedures for patients as well as correct hand hygiene, correct vascular access manipulation, correct isolation procedures according to the via of pathogen spreading, and the use of HEPA filters can be all of great utility in the prevention of difficult to treat infections in HSCT.

Vaccines represent also an important tool for prevention of viral and bacterial (S. pneumoniae) infections in the post transplant setting. 
Table 28.3 Prophylaxis and therapy of IFI in children undergoing allogeneic HSCT

\section{Voriconazole}

Spectrum of activity: molds, yeasts

Prophylaxis: No evidence to support this indication in children. Dosage in children aged 2 to $<12$ years or $12-14$ years with weight $<50 \mathrm{~kg}$ : $9 \mathrm{mg} / \mathrm{kg}$ q12h; In children aged $\geq 15$ years or $12-14$ years and with weight $\geq 50 \mathrm{~kg}$ : $4 \mathrm{mg} / \mathrm{kg} \mathrm{q} 12 \mathrm{~h}$ (1st day, $6 \mathrm{mg} / \mathrm{kg}$ ). Target concentration $>1$ and $<6 \mathrm{mg} / \mathrm{L}$ at steady state

Therapy: Dosage in children aged 2 to $<12$ years or $12-14$ years with weight $<50 \mathrm{~kg}$ : $9 \mathrm{mg} / \mathrm{kg} \mathrm{q} 12 \mathrm{~h}$; In children aged $\geq 15$ years or $12-14$ years with weight $\geq 50 \mathrm{~kg}: 4 \mathrm{mg} / \mathrm{kg} \mathrm{q} 12 \mathrm{~h}$ ( $1 \mathrm{st}$ day, $6 \mathrm{mg} / \mathrm{kg}$ ). Target concentration $>1$ and $<6 \mathrm{mg} / \mathrm{L}$ at steady state.

Notes: Measure serum concentrations (mandatory) before the 5th dose (2 days of treatment); before the 5th dose following any dose adjustment; routinely every 1-2 weeks after achievement of steady-state; when interacting drugs start or stop in case of potential clinical or laboratory manifestations of toxicity

\section{Posaconazole}

Spectrum of activity: molds, yeasts

Prophylaxis: Oral suspension: $120 \mathrm{mg} / \mathrm{m}^{2} \mathrm{q} 8 \mathrm{~h}$ for children who can not swallow tablets. Tablets: loading dose of $300 \mathrm{mg}$ q12h (1st day) then maintenance 300 q24h, independently from meal. According with BW:

\begin{tabular}{|l|l|l|}
\hline Body weight & Load (1st day) & Maintenance \\
\hline $15-21 \mathrm{~kg}$ & $150 \mathrm{mg} \mathrm{q} 12 \mathrm{~h}$ & $100 \mathrm{mg}$ q24h \\
\hline $22-30 \mathrm{~kg}$ & $150 \mathrm{mg} \mathrm{q} 12 \mathrm{~h}$ & $150 \mathrm{mg} \mathrm{q} 24 \mathrm{~h}$ \\
\hline $31-35 \mathrm{~kg}$ & $200 \mathrm{mg} \mathrm{q} 12 \mathrm{~h}$ & $200 \mathrm{mg} \mathrm{q} 24 \mathrm{~h}$ \\
\hline $35-40 \mathrm{~kg}$ & $250 \mathrm{mg} \mathrm{q} 12 \mathrm{~h}$ & $250 \mathrm{mg} \mathrm{q} 24 \mathrm{~h}$ \\
\hline$>40 \mathrm{~kg}$ or 13 years & $300 \mathrm{mg} \mathrm{q} 12 \mathrm{~h}$ & $300 \mathrm{mg} \mathrm{q} 24 \mathrm{~h}$ \\
\hline
\end{tabular}

Target concentration for prophylaxis $0.7 \mathrm{mg} / \mathrm{L}$ at steady state. Not registered for use $<18$ years

Therapy: Oral suspension: $120 \mathrm{mg} / \mathrm{m}^{2} \mathrm{q} 8 \mathrm{~h}$ for children who cannot swallow tablets. Tablets: loading dose of $300 \mathrm{mg}$ q12h (1st day) then maintenance 300 q24h, independently from meal. According with BW:

\begin{tabular}{|l|l|l|}
\hline Body weight & Load(1st day) & Maintenance \\
\hline $15-21 \mathrm{~kg}$ & $150 \mathrm{mg} \mathrm{q12h}$ & $100 \mathrm{mg}$ q24h \\
\hline $22-30 \mathrm{~kg}$ & $150 \mathrm{mg} \mathrm{q12h}$ & $150 \mathrm{mg}$ q24h \\
\hline $31-35 \mathrm{~kg}$ & $200 \mathrm{mg} \mathrm{q} 12 \mathrm{~h}$ & $200 \mathrm{mg}$ q24h \\
\hline $35-40 \mathrm{~kg}$ & $250 \mathrm{mg} \mathrm{q} 12 \mathrm{~h}$ & $250 \mathrm{mg}$ q24h \\
\hline $40 \mathrm{~kg}$ or 13 years & $300 \mathrm{mg} \mathrm{q} 12 \mathrm{~h}$ & $300 \mathrm{mg}$ q24h
\end{tabular}

Target concentration for therapy $\geq 1 \mathrm{mg} / \mathrm{L}$ at steady state. Not registered for use $<18$ years

Notes: When using oral suspension remove acid suppression if possible and use "posaconazole bundle":

- ascorbic acid $500 \mathrm{mg}$ per os with each dose of posaconazole

-120-180 mL of carbonated soda beverage (i.e.: cola or ginger ale) or acidic fruit juice (e.g.: cranberry or orange juice) with each dose of posaconazole

- heavy snack or food with each dose, preferably high-fat, including

- use a more fractionated schedule (q 6-8h)

With any formulation measure serum concentrations (mandatory): 7 days after initiation of therapy or following dose adjustment or when interacting drugs start or stop or in case of concerns about GI absorption, especially for prolonged periods of time or in case of potential clinical or laboratory manifestations of toxicity

\section{Itraconazole}

Spectrum of activity: molds, yeasts

Prophylaxis: Moderate evidence to support a recommendation in children. Oral solution $2.5 \mathrm{mg} / \mathrm{kg}$ per day orally (in children aged $\geq 2$ years) $\mathrm{q} 12 \mathrm{~h}$, with empty stomach. Target concentration for prophylaxis $0.5 \mathrm{mg} / \mathrm{L}$ at steady state Notes: Measure serum concentrations. For oral administration use oral solution. Administer with empty stomach

\section{Fluconazole}

Spectrum of activity: yeast

Prophylaxis: Not highly recommendable because of the narrow spectrum (yeasts only). $6 \mathrm{mg} / \mathrm{kg} / \mathrm{day}$ (maximum $400 \mathrm{mg}$ / day) intravenously or orally q24h

Therapy: 10-20 mg/kg/day, maximum $800 \mathrm{mg} /$ day) intravenously or orally q24h

Spectrum of activity: molds, yeasts

\section{Liposomal amphotericin B}

Prophylaxis: Moderate evidence to support intravenous, no evidence for nebulized administration Intravenous: $1 \mathrm{mg} /$ $\mathrm{kg}$ q24h every other day or $2.5 \mathrm{mg} / \mathrm{kg}$ q24h twice weekly; Nebulized: $25 \mathrm{mg}$ q12h on 2 consecutive days per week associated with fluconazole

Therapy: Intravenous: 3-5 mg/kg according to etiology. Doses up to $10 \mathrm{mg} / \mathrm{kg}$ have been proposed for mucormycosis 
Table 28.3 (continued)

\begin{tabular}{|c|}
\hline Micafungin \\
\hline $\begin{array}{l}\text { Spectrum of activity: yeast (not Cryptococcus) (molds?) } \\
\text { Prophylaxis: Not highly recommendable because of the narrow spectrum (yeasts only) } \\
1 \mathrm{mg} / \mathrm{kg} \text { (in children weighing } \geq 50 \mathrm{~kg}, 50 \mathrm{mg}) \mathrm{q} 24 \mathrm{~h} \\
\text { Therapy: } 2-4 \mathrm{mg} / \mathrm{kg}(\max 100 \mathrm{mg} / \mathrm{kg}) \mathrm{q} 24 \mathrm{~h}\end{array}$ \\
\hline Isavuconazole \\
\hline $\begin{array}{l}\text { Spectrum of action: molds, yeasts } \\
\text { Prophylaxis: No evidence for this indication. No data for pediatric use and dosage. Not registered }<18 \text { years } \\
\text { Therapy: No data for pediatric use and dosage. Not registered }<18 \text { years }\end{array}$ \\
\hline Corimoxazole, dapsone, atovaquone, pentamidine \\
\hline $\begin{array}{l}\text { Spectrum of action: P. Jirovecii } \\
\text { Prophylaxis: Cotrimoxazole } 1 \mathrm{st} \text { choice: } 2.5 \mathrm{mg} / \mathrm{kg} \text { of trimethoprim }(\max 180 \mathrm{mg}) \mathrm{q} 12 \mathrm{~h}, 1-3 \text { days/week } \\
\text { Therapy: Cotrimoxazole } 1 \mathrm{st} \text { choice: } 5 \mathrm{mg} / \mathrm{kg} \text { of trimethoprim q8h } \\
\text { Notes: In case op pneumonia add prednisone at } 2 \mathrm{mg} / \mathrm{kg} / \mathrm{day} \text {. Nebulized pentamidine requires special tools for } \\
\text { administration }\end{array}$ \\
\hline
\end{tabular}

IFI invasive fungal infection

\section{Key Points}

Many of the conditions requiring alloHSCT and related complications are similar in adults and children and are covered in other chapters of this handbook.

However, since pediatric age is a continuum between newborns and adults, there are at least two aspects:

- Psychological aspects. Childhood encompasses different ages and consequently different cognitive, decisional, and emotional capacities that make psychological intervention far more faceted than in adults.

- Infectious diseases. Data on epidemiology and management of infections in children are far less numerous and consistent than in adults. Despite that there are many differential aspects in its management.

\section{References}

Bernhard S, Kernland Lang K, et al. Voriconazoleinduced phototoxicity in children. Pediatr Infect Dis J. 2012;31:769-71.

Calitri C, Caviglia I, Cangemi G, et al. Performance of $1,3-\beta$-D-glucan for diagnosing invasive fungal diseases in children. Mycoses. 2017;60:789-95.
Caselli D, Cesaro S, Fagioli F, et al. Incidence of colonization and bloodstream infection with carbapenem-resistant Enterobacteriaceae in children receiving antineoplastic chemotherapy in Italy. Infect Dis (Lond). 2016;48:152-5.

Castagnola E, Bagnasco F, Amoroso L, et al. Role of management strategies in reducing mortality from invasive fungal disease in children with cancer or receiving hemopoietic stem cell transplant: a single center 30-year experience. Pediatr Infect Dis J. 2014;33:233-7.

Castagnola E, Bagnasco F, Menoni S, et al. Risk factors associated with development and mortality by invasive fungal diseases in pediatric allogeneic stem cell transplantation. A pediatric subgroup analysis of data from a prospective study of the Gruppo Italiano Trapianto di Midollo Osseo (GITMO). Bone Marrow Transplat. 2018;53:1193. https://doi.org/10.1038/ s41409-018-0160-2.

Castagnola E, Mesini A. Antifungal prophylaxis in children receiving antineoplastic chemotherapy. Curr Fungal Infect Rep. 2018;12:78. https://doi. org/10.1007/s12281-018-0311-3.

Castagnola E, Ruberto E, Guarino A. Gastrointestinal and liver infections in children undergoing antineoplastic chemotherapy in the years 2000. World J Gastroenterol. 2016;22:5853-66.

Cesaro S, Tridello G, Castagnola E, et al. Retrospective study on the incidence and outcome of proven and probable invasive fungal infections in high-risk pediatric onco-hematological patients. Eur J Haematol. 2017;99:240-8.

Devine KA, Manne SL, Mee L, et al. Barriers to psychological care among primary caregivers of children undergoing hematopoietic stem cell transplantation. Support Care Cancer. 2016;24:2235-42.

Enoch DA, Butler MJ, Pai S, et al. Clostridium difficile in children: colonisation and disease. J Infect. 2011;63:105-13. 
European Medicine Agency. Posaconazole summary of product characteristics. www.ema.europa.eu. Last check 15 Mar 2018.

Fisher BT, Robinson PD, Lehrnbecher T, et al. Risk factors for invasive fungal disease in pediatric cancer and hematopoietic stem cell transplantation: a systematic review. J Pediatr Infect Dis Soc. 2017. https://doi. org/10.1093/jpids/pix030. [Epub ahead of print].

Gerhardt CA, Lehmann V, Long KA, Alderfer MA. Supporting siblings as a standard of care in pediatric oncology. Pediatr Blood Cancer. 2015;62(Suppl 5):S750-804.

Girmenia C, Rossolini GM, Piciocchi A, et al. Infections by carbapenem-resistant Klebsiella pneumoniae in SCT recipients: a nationwide retrospective survey from Italy. Bone Marrow Transplant. 2015;50:282-8.

Goyal RK, Gehris RP, Howrie D. Phototoxic dermatoses in pediatric BMT patients receiving voriconazole. Pediatr Blood Cancer. 2014;61:1325-8.

Groll AH, Castagnola E, Cesaro S, et al. Fourth European Conference on Infections in Leukaemia (ECIL-4): guidelines for diagnosis, prevention, and treatment of invasive fungal diseases in paediatric patients with cancer or allogeneic haemopoietic stem-cell transplantation. Lancet Oncol. 2014;15(8):e327-40.

Heinz WJ, Cabanillas Stanchi KM, Klinker H, et al. Posaconazole plasma concentration in pediatric patients receiving antifungal prophylaxis after allogeneic hematopoietic stem cell transplantation. Med Mycol. 2016;54:128-37.

Heinze KE, Rodday AM, Nolan MT, et al. The impact of pediatric blood and marrow transplant on parents: introduction of the parent impact scale. Health Qual Life Outcomes. 2015;13:46.

Jancel T, Shaw PA, Hallahan CW, et al. Therapeutic drug monitoring of posaconazole oral suspension in paediatric patients younger than 13 years of age: a retrospective analysis and literature review. J Clin Pharm Ther. 2017;42:75-9.

Kelly DL, Buchbinder D, Duarte RF, et al. Neurocognitive dysfunction in hematopoietic cell transplant recipients: expert review from the late effects and Quality of Life Working Committee of the Center for International Blood and Marrow Transplant Research and complications and Quality of Life Working Party of the European Society for Blood and Marrow Transplantation. Biol Blood Marrow Transplant. 2018;24:228-41.

Lees EA, Miyajima F, Pirmohamed M, Carroll ED. The role of Clostridium difficile in the paediatric and neonatal gut - a narrative review. Eur J Clin Microbiol Infect Dis. 2016;35:1047-57.

Lehrnbecher T, Robinson PD, Fisher BT, et al. Galactomannan, $\beta$-D-glucan, and polymerase chain reaction-based assays for the diagnosis of invasive fungal disease in pediatric cancer and hematopoietic stem cell transplantation: a systematic review and meta-analysis. Clin Infect Dis. 2016;63:1340-8.

Lehrnbecher T, Robinson P, Fisher B, et al. Guideline for the management of fever and neutropenia in children with cancer and hematopoietic stem-cell transplantation recipients: 2017 update. J Clin Oncol. 2017;35:2082-94.

Loiselle KA, Rausch JR, Bidwell S, et al. Predictors of health-related quality of life over time among pediatric hematopoietic stem cell transplant recipients. Pediatr Blood Cancer. 2016;63:1834-9.

Mesini A, Faraci M, Giardino S, et al.. Alternate day dosing of posaconazole tablets in children leads to efficient plasma levels. Eur J Haematol. 2018 Mar 15. https://doi.org/10.1111/ejh.13063. [Epub ahead of print].

Natale S, Bradley J, Huy Nguyen W, et al. Pediatric obesity: pharmacokinetic alterations and effects on antimicrobial dosing. Pharmacotherapy. 2017;37:361-78.

Neely M, Margol A, Fu X, et al. Achieving target voriconazole concentrations more accurately in children and adolescents. Antimicrob Agents Chemother. 2015;59:3090-7.

Packman W, Weber S, Wallace J, Bugescu N. Psychological effects of hematopoietic SCT on pediatric patients, siblings and parents: a review. Bone Marrow Transplant. 2010;45:1134-46.

Phipps S, Dunavant M, Lensing S, Rai SN. Psychosocial predictors of distress in parents of children undergoing stem cell or bone marrow transplantation. J Pediatr Psychol. 2005;30:139-53.

Soler-Palacın P, Frick MA, Martın-Nalda A, et al. Voriconazole drug monitoring in the management of invasive fungal infection in immunocompromised children: a prospective study. J Antimicrob Chemother. 2012;67:700-6.

Steele AC, Mullins LL, Mullins AJ, Muriel AC. Psychosocial interventions and therapeutic support as a standard of care in pediatric oncology. Pediatr Blood Cancer. 2015;62(Suppl 5):S585-618.

Teusink A, Vinks A, Zhang K, et al. Genotype-directed dosing leads to optimized voriconazole levels in pediatric patients receiving hematopoietic stem cell transplantation. Biol Blood Marrow Transplant. 2016;22(3):482-6. e-pub ahead of print 2015/12/01. https://doi.org/10.1016/j.bbmt.2015.11.011.

Tomà $\mathrm{P}$, Bertaina $\mathrm{A}$, Castagnola $\mathrm{E}$, et al. Fungal infections of the lung in children. Pediatr Radiol. 2016;46:1856-65.

Virtue SM, Manne SL, Mee L, et al. Psychological distress and psychiatric diagnoses among primary caregivers of children undergoing hematopoietic stem cell transplant: an examination of prevalence, correlates, and racial/ethnic differences. Gen Hosp Psychiatry. 2014;36:620-6.

White TE, Hendershot KA, Dixon MD, et al. Family strategies to support siblings of pediatric hematopoietic stem cell transplant patients. Pediatrics. 2017;139(2):e20161057. e-pub ahead of print 2017/01/26. https://doi.org/10.1542/ peds.2016-1057.

Xu G, Zhu L, Ge T, Liao S, Qi F. Pharmacokinetic/ pharmacodynamic analysis of voriconazole against Candida spp. and Aspergillus spp. in children, adolescents and adults by Monte Carlo simulation. Int $\mathbf{J}$ Antimicrob Agents. 2016;47:439-45. 
Open Access This chapter is licensed under the terms of the Creative Commons Attribution 4.0 International License (http://creativecommons.org/licenses/by/4.0/), which permits use, sharing, adaptation, distribution and reproduction in any medium or format, as long as you give appropriate credit to the original author(s) and the source, provide a link to the Creative Commons license and indicate if changes were made.

The images or other third party material in this chapter are included in the chapter's Creative Commons license, unless indicated otherwise in a credit line to the material. If material is not included in the chapter's Creative Commons license and your intended use is not permitted by statutory regulation or exceeds the permitted use, you will need to obtain permission directly from the copyright holder.

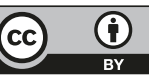

